\title{
ON THE INFLUENCES OF THE $E L$ NIÑO, LA NIÑA AND ATLANTIC DIPOLE PATTERN ON THE AMAZONIAN RAINFALL DURING 1960-1998
}

\author{
Everaldo B. de SOUZA', Mary T. KAYANO', Julio TOTA', Luciano PEZZI'², \\ Gilberto FISCH${ }^{3}$, Carlos NOBRE ${ }^{2}$
}

\begin{abstract}
The influence of the large-scale climatic variability dominant modes in the Pacific and in the Atlantic on Amazonian rainfall is investigated. The composite technique of the Amazon precipitation anomalies is used in this work. The basis years for these composites are those in the period 1960-1998 with occurrences of extremes in the Southern Oscillation (El Niño or La Niña) and the north/south warm (or cold) sea surface temperature (SST) anomalies dipole pattern in the tropical Atlantic. Warm (cold) dipole means positive (negative) anomalies in the tropical North Atlantic and negative (positive) anomalies in the tropical South Atlantic. Austral summer and autumn composites for extremes in the Southern Oscillation (El Niño or La Niña) and independently for north/south dipole pattern (warm or cold) of the SST anomalies in the tropical Atlantic present values (magnitude and sign) consistent with those found in previous works on the relationship between Amazon rainfall variations and the SST anomalies in the tropical Pacific and Atlantic. However, austral summer and autumn composites for the years with simultaneous occurrences of El Niño and warm north/south dipole of the SST anomalies in the tropical Atlantic show negative precipitation anomalies extending eastward over the center-eastern Amazon. This result indicates the important role played by the tropical Atlantic in the Amazon anomalous rainfall distribution.
\end{abstract}

Key words: Seasonal rainfall, ENSO, Amazon, SST anomalous north-south dipole in the Atlantic.

Sobre a Influência do El Niño, La Niña e Padrão De Dipolo do Atlântico na precipitação da amazônia durante 1960-1998

RESUMO - A influência dos modos de variabilidade climática de grande escala dominantes no Pacifico e Atlântico nas chuvas da Amazônia é investigada. A técnica de compósitos das anomalias de precipitação na Amazônia é usada neste trabalho. Os anos base destes compósitos são aqueles do periodo 1960-1998 com ocorrências de extremos na Oscilação Sul (El Niño ou La Niña) e de padrão de dipolo norte/sul quente (ou frio) nas anomalias de TSM no Atlântico tropical. Dipolo quente (frio) significa anomalias positivas (negativas) no Atlàntico tropical Norte e negativas (positivas) no Atlântico tropical Sul. Compósitos de verão c outono austrais para extremos na Oscilação Sul (El Niño ou La Niña) e independente para padrào de dipolo norte/sul (quente ou frio) de anomalias de TSM no Atlântico tropical, apresentam valores (magnitude e signal) consistentes com aqueles encontrados em trabalhos anteriores sobre a relação entre as variações de precipitação na Amazônia e anomalias de TSM no Pacifico e Atlântico tropicais. No entanto, compósitos dos verões c outonos austrais para os anos com ocorrências simultâneas de El Niño e dipolo quente norte/sul de anomalias de TSM no Atlântico tropical mostram anomalias negativas de precipitação estendendo-se para leste sobre a Amazônia centro-leste. Este resultado indica o importante papel desempenhado pelo Atlântico tropical na distribuição anômala de precipitação na Amazónia.

Palavras-chave: Chuva sazonal, ENOS, Amazônia, Dipolo norte-sul de anomalias de TSM.

'Instituto Nacional de Pesquisas Espaciais (INPE), São José dos Campos, 12227-010, SP, Brasil. ${ }^{2}$ Centro de Previsão de Tempo e Estudos Climáticos (CPTEC/INPE), Cachoeira Paulista, 12630000, SP, Brasil.

${ }^{3}$ Centro Técnico Aeroespacial (CTA/IAE-ACA), São José dos Campos, 12228-904, SP, Brasil. 


\section{INTRODUCTION}

The so-called Brazilian Legal Amazon (hereafter Amazon) includes an area of approximately 5 million $\mathrm{km}^{2}$ comprising the states of Pará, Amazonas, Rondônia, Acre, Roraima, Amapá, western sector of Maranhão and center-northern parts of Tocantins and Mato Grosso. Most of the annual total rainfall over the Amazon occurs during the austral summer (December to February) and autumn (March to May) months. Figure 1 shows seasonal percentages of the annual total precipitation. The summer rainfall accounts for the highest percentages of the annual total with the largest values increasing from the northern sector towards the central and southern sectors (Fig. 1a). The autumn shows an inverse pattern, i.e., with the highest percentages ranging from $40 \%$ to $48 \%$ in the northern sector (particularly the oriental Amazon) and the lowest values spanning from $24 \%$ to $27 \%$ in the southern sector. The austral winter (June to August) and spring (September to November) rainfall over the Amazon accounts for considerably smaller seasonal percentages. These results are consistent with previous findings on the climatological distribution of the Amazon rainfall (Rao and Hada, 1990; Quadro et al., 1996).

The dynamical aspects of the large-scale atmospheric circulation and the small-scale systems, which are directly or indirectly related to climatological precipitation distribution over the Amazon, have been previously addressed. The strong seasonal superficial heating during the austral summer and autumn causes deep convection and defines the Amazon rainy period. However, atmospheric instabilities generated by synoptic-scale meteorological systems can further intensify the convection. Some of these systems are mainly related to the seasonal cycle of atmospheric circulation, such as the Bolivian upper-tropospheric high (Kousky and Kayano, 1981; Jones and Horel, 1990) and the Intertropical Convergence Zone (ITCZ). The ITCZ migrates southward during the austral summer and autumn inducing widespread precipitation mainly in the center-eastern Amazon by the end of the summer and beginning of the autumn (Nobre and Shukla, 1996). Cold fronts originating in the austral extratropics may also affect convection in the Amazon. This is the case of cold fronts moving towards low latitudes, reaching mainly the Rondônia State and causing cold outbreaks (known as friagem by local people) (Marengo et al., 1997). Also, strong frontal systems located in central and southeastern Brazil (Oliveira and Nobre, 1985; Paegle, 1987) and the South Atlantic Convergence Zone (SACZ) (Kousky, 1985; Figueroa and Nobre, 1990; Obregon and Nobre, 1990; Figueroa et al., 1995) may interact with the tropical convection, enhancing and organizing deep convection over the whole Amazon. In addition, squall lines trigged by sea breezes along the eastern coast move into the central Amazon (Cohen et al., 1995) and intensify convection. Molion (1987) and Fisch et al. (1998) provide a review of the dynamic as- 

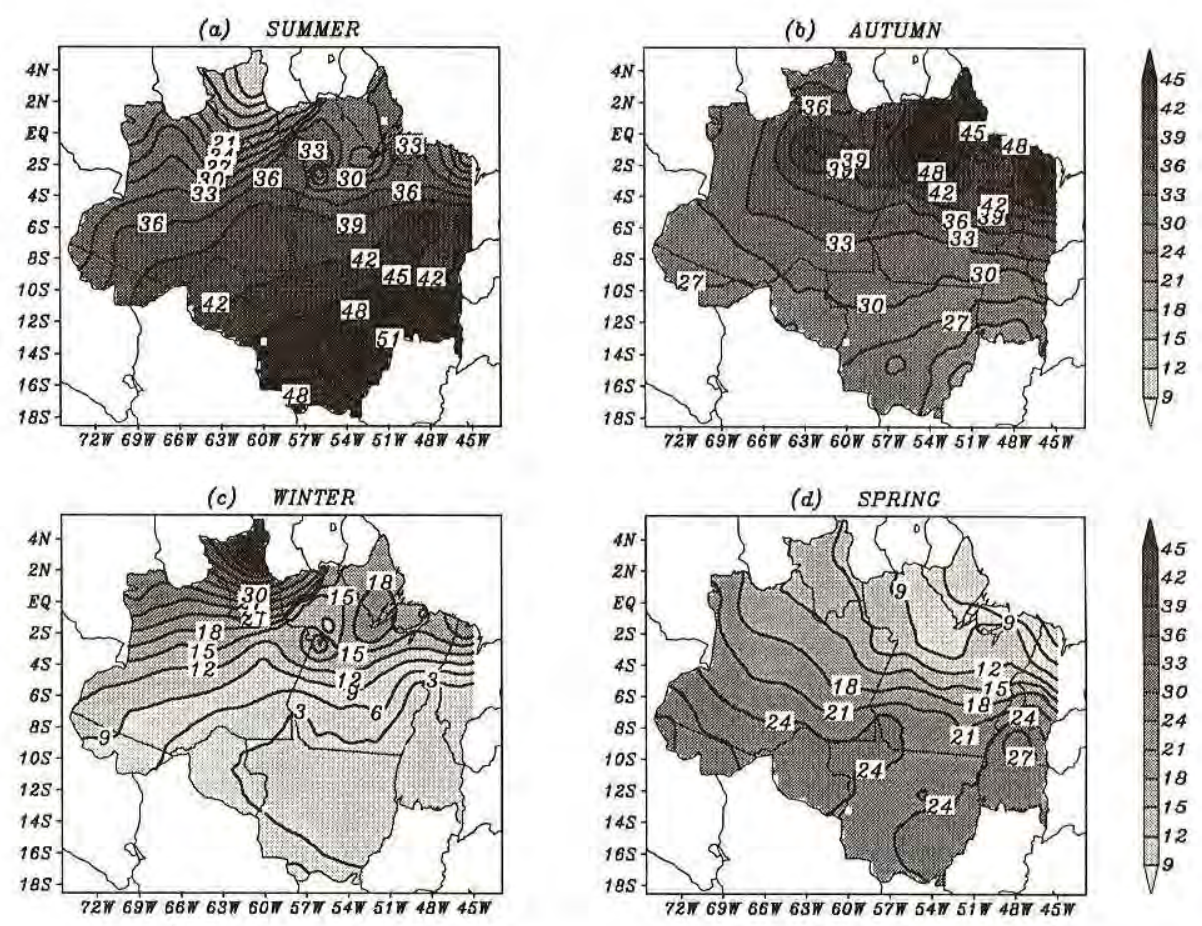

Figure 1. Precipitation percentage of the annual total over Amazon for austral: (a) summer, (b) autumn, (c) winter, and (d) spring. The contour interval is $3 \%$.

pects of these meteorological systems in the Amazon.

In addition, the tropical Pacific and Atlantic Oceans adjacent to the Amazon play an important role in the interannual climatic variability of this region. The large-scale climatic mode of the tropical Pacific, the so-called El Niño/Southern Oscillation (ENSO), has a cycle, with the El Niño manifesting in one extreme phase and the $L a$ Niña in the opposite extreme. The major atmospheric and oceanic features associated with El Niño events are: surface waters warmer than normal over tropical central and eastern Pacific; trade winds weaker than nor$\mathrm{mal}$ and sea level pressure (SLP) lower than normal in eastern Pacific and higher than normal in western Pacific. La Niña episodes feature reversed atmospheric and oceanic patterns. The ENSO can cause extreme climatic anomalies in several tropical areas around the world (Ropelewski and Halpert, 1987). The northernnortheastern sector of South America is one such area and comprises a substantial part of the center-eastern Amazon (Kousky and Ropelewski, 1989). In general, El Niño episodes are associated with dry rainy season in the Amazon (Nobre and Rennó, 1985; Kayano and Moura, 1986; Marengo and Hastenrath, 1993). Specific studies are in the literature concerning the 
La Niña influences on Amazon precipitation.

Indeed, the ENSO impacts on the climate over Brazil have been studied with more emphasis to the $E l$ Niño phenomenon. The associated large-scale ocean-atmosphere interactions in the tropical Pacific cause changes in the Walker Cell (a largescale atmospheric circulation in the zonal direction with ascending branch over western Pacific and descending branch over eastern Pacific) and in the Hadley Cell (large-scale atmospheric circulation in the meridional direction with ascending branch over tropics and descending branch over sub-tropics). Kousky et al. (1984) and Kousky and Ropelewski (1989) suggested that most droughts over northern-northeastern Brazil, when associated with El Niño events, are manifestations of changed Walker Cell with an anomalous subsiding branch over the North Atlantic including the oriental Amazon and northern part of Northeast Brazil.

The sea surface temperature (SST) in the tropical Atlantic at times also features a dominant large-scale mode, in particular during the austral autumn, with a north/south dipole pattern (Moura and Shukla, 1981; Nobre and Shukla, 1996). This pattern is characterized by the simultaneous manifestation of SST anomalies with opposite signs over areas of the tropical North and South Atlantic. Warm (cold) dipole is characterized by the simultaneous occurrences of positive (negative) SST anomalies in the tropical North Atlantic and negative (positive) SST anomalies in the tropical
South Atlantic. As a consequence of the north/south dipole a meridional interhemispheric thermal gradient establishes in the equatorial Atlantic (Wagner, 1996). The related variations in the SST, trade winds and SLP are crucial in steering the intensity and positioning of the cloudiness and precipitation band associated with the ITCZ. For warm (cold) dipole pattern, the ITCZ tends to position predominantly to the north (south) of its climatological position (Nobre and Shukla, 1996; Souza and Nobre, 1998).

Both, the ENSO cycles and the north/south SST dipole pattern in the Atlantic affect precipitation in the Amazon. Thus, the main purpose of this paper is to improve our understanding of the relationship between the large-scale climatic dominant modes in the tropical oceans adjacent to the Amazon and the precipitation in this region.

\section{DATA AND METHODOLOGY}

The data used consist of monthly precipitation records for the period 1960-1998 for 82 raingauge stations in the Amazon obtained from the Instituto Nacional de Meteorologia (INMET) of Brazil. Figure 2 shows the locations of these stations. Due to a poor coverage of raingauge stations in the central and northern Amazon sectors the data are interpolated into a regular grid of $0.25^{\circ}$ latitude and longitude resolution using the Kriging method. Monthly SST data are obtained from two datasets. The SST data for the period 1960-1993 are ex- 
tracted from the version compiled by Da Silva et al. (1994) of Comprehensive Ocean-Atmosphere Data Set (COADS) which contains monthly global fields in a grid of $1^{\circ}$ latitude and longitude resolution. The SST data for the period 1994-1998 are obtained anomalies are averaged in two areas, one in the North Atlantic limited at $5^{\circ} \mathrm{N}, 25^{\circ} \mathrm{N}, 50^{\circ} \mathrm{W}$ and $20^{\circ} \mathrm{W}$ and another in the South Atlantic limited at $5^{\circ} \mathrm{S}, 25^{\circ} \mathrm{S}, 30^{\circ} \mathrm{W}$ and the Greenwich meridian. The warm dipole years are defined as those with simultaneous

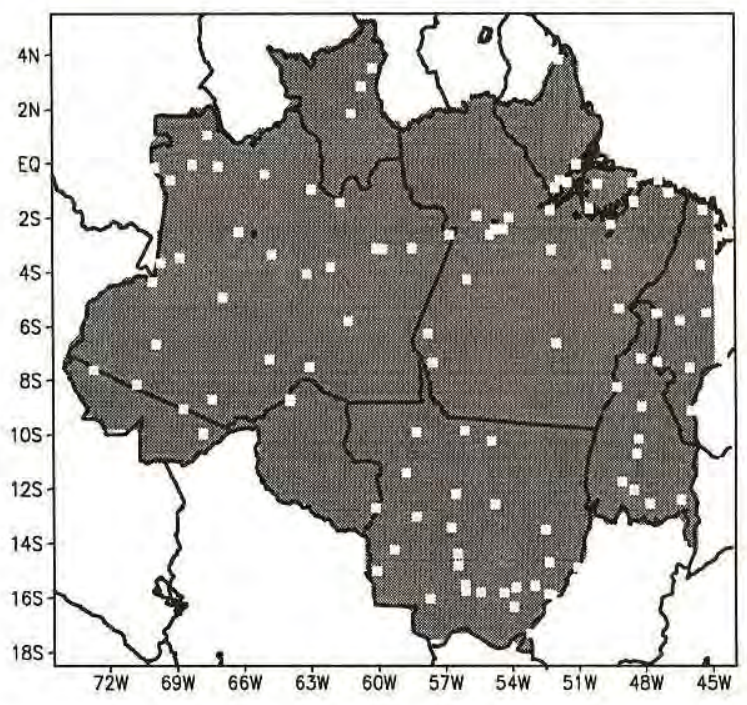

Figure 2. Locations of the INMET raingauge stations over Amazon.

from the monthly global fields with horizontal resolution of $1^{\circ}$ in latitude and longitude routinely made available at the National Centers for Environmental Prediction (Reynolds, 1988).

As recommended by Trenberth (1997), El Niño (La Niña) years are defined as those with three consecutive monthly average SST anomalies $\geq+0.5^{\circ} \mathrm{C}\left(\leq-0.5^{\circ} \mathrm{C}\right)$ for the months of October, November and December in the NINO3 area $\left(5^{\circ} \mathrm{N}-5^{\circ} \mathrm{S} / 145^{\circ} \mathrm{W}\right.$ $\left.90^{\circ} \mathrm{W}\right)$. Figure 3 a shows the SST anomalies averaged in the NINO3 area from June to December. For the selection of dipole years monthly SST occurrences of three consecutive monthly SST anomalies $\geq+0.2^{\circ} \mathrm{C}$ over the North Atlantic area and monthly SST anomalies $\leq-0.2^{\circ} \mathrm{C}$ over the South Atlantic area, for March, April and May (period with a better definition of the dipole pattern mode). The cold dipole years are defined as those having an inverse north/south SST anomalous pattern. Figure $3 \mathrm{~b}$ shows the time series of the monthly SST anomalies spatially averaged in the two areas defined in the tropical Atlantic for the months from January to June. Table 1 is derived from Figure 3 and displays the years included in the period 
1960-1998 with occurrences of El the onset of warm (or cold) dipole.

Niño, La Niña, warm and cold dipoles in the Atlantic. The years listed in Table 1 are then used as the basis to

\section{RESULTS}

Figure 4 shows the austral sum-

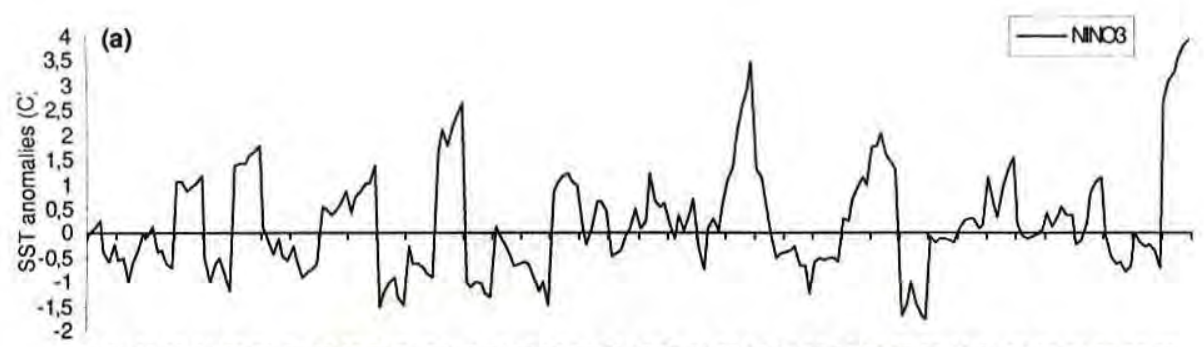

6061626364656667686970717273747576777879808182838485868788899091929394959697

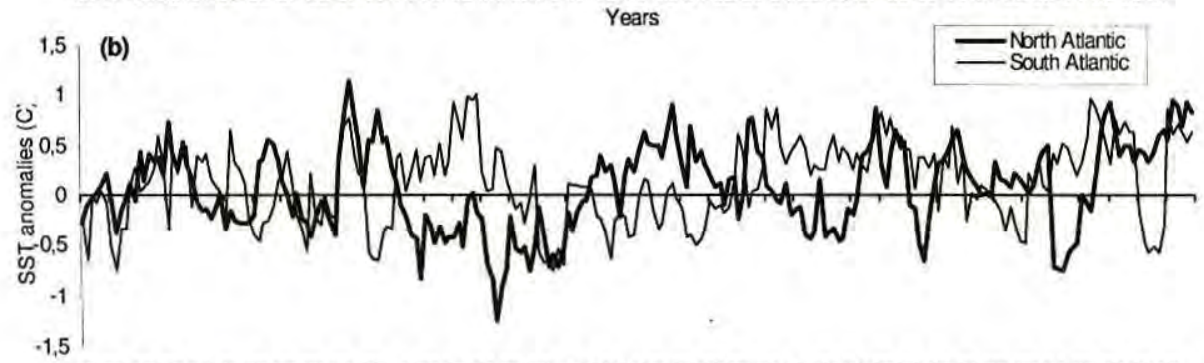

606162636465666768697071727374757677787980818283848586878889909192939495969798 Years

Figure 3. Time series of the monthly SST anomalies $\left({ }^{\circ} \mathrm{C}\right)$ spatially averaged in the areas of the (a) NINO3 and (b) North Atlantic (solid line) and South Atlantic (thin line). The values from June to December are plotted for NINO3, and the values from January to June are plotted for North and South Atlantic areas.

Table 1. Years of the occurrences of El Niño, La Niña events and warm and cold dipole in the tropical Atlantic during the period from 1960 to 1998.

\begin{tabular}{ccccc}
\hline Phenomenon: & EL NIÑO & LA NIÑA & WARM DIPOLE & COLD DIPOLE \\
\hline & & & & \\
Years of & $63,65,68,69,72,76$, & $61,64,67,70,71,73$, & $66,70,78,79$, & $64,65,71,72,73,74$, \\
occurrence: & $79,82,86,87,91,94,97$ & $75,84,85,88,95$ & $80,81,92,97$ & $77,85,86,89,94$ \\
\hline
\end{tabular}

compute the Amazon precipitation composites for the austral summer and autumn seasons. For the austral summer composites and for ENSO cases, December is taken on the onset year of $E l$ Niño (or La Niña), and for the dipole cases, it is taken on the previous year of mer and autumn composites of precipitation anomalies (mm/month) for the El Niño years. The positive (negative) anomalies indicate precipitation above (below) the climatological values for each season. El Niño events affect more strongly the summer pre- 
cipitation than the autumn precipitation in the Amazon (Fig. 4). Indeed, most of the Amazon experiences deficient precipitation during summer with negative anomalies in almost the whole area and values lower than -50 $\mathrm{mm} / \mathrm{month}$ in its central and northern parts. For autumn, negative anomalies are observed in a smaller area, which includes Roraima State, the northern sector of Amazonas State, eastern Pará
Niña years. During austral summer, the La Niña composite (Fig. 5a) features nearly opposite patterns than that observed for the El Niño composite (Fig. 4a) for this same season. In fact, Figure 5a shows positive values over the center-northern Amazon and negative anomalies in the southeastern and eastern Amazon. On the other hand, La Niña episodes have stronger influence on the autumn rainfall over the
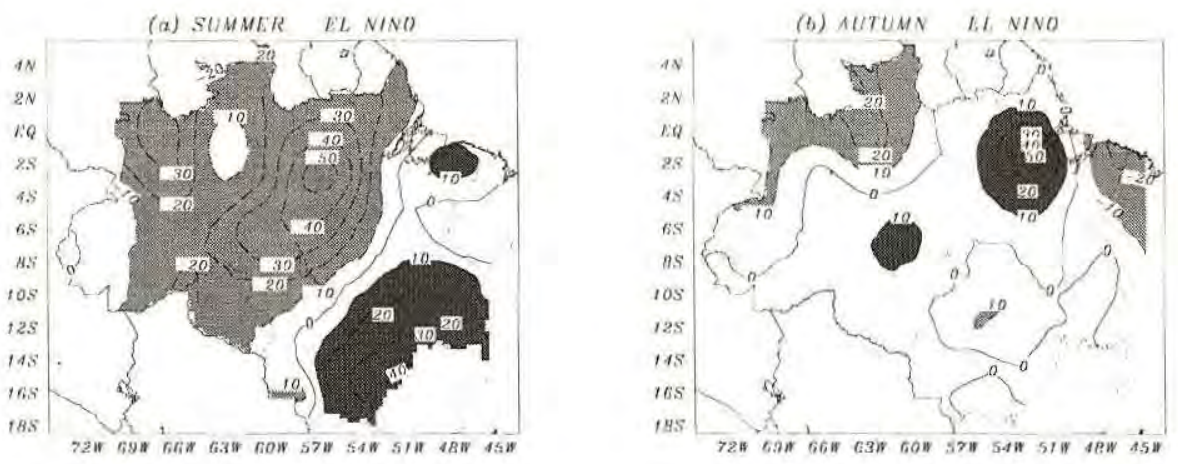

Figure 4. Composites of precipitation anomalies over the Amazon for El Niño years for: (a) austral summer and (b) austral autumn. The contour interval is $10 \mathrm{~mm} / \mathrm{month}$. Solid (dashed) lines correspond to the positive (negative) anomalies.

and Maranhão. In both seasons, positive anomalies are found over the southeastern Amazon (Mato Grosso and Tocantins). It is worthwhile to mention the occurrence of positive anomalies over northeastern Pará centered near Altamira area during autumn. This might be related to the action of meso-scale systems, such as squall lines along the eastern coast of the Amazon, in agreement with the results of Cohen et al. (1995).

Figure 5 shows the austral summer and autumn anomalous precipitation composites (mm/month) for $L a$
Amazon than the El Niño events. The Autumn composite for La Niña events shows positive precipitation anomalies spanning from $10 \mathrm{~mm} /$ month to 40 $\mathrm{mm} / \mathrm{month}$ extending over a large area in the center-eastern and northeastern Amazon.

Figure 6 shows the austral summer and autumn anomalous precipitation composites ( $\mathrm{mm} / \mathrm{month}$ ) for warm dipole years. The austral summer composite exhibits negative values in the center-northern and western sectors of the Amazon and positive values in its center-eastern part (Fig. 6a). 


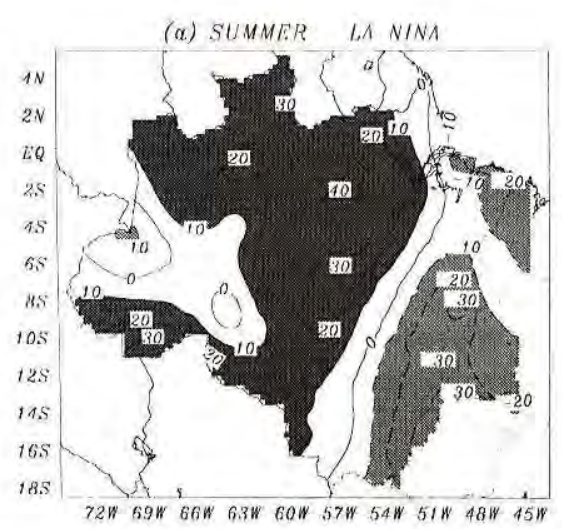

Figure 5. As in Fig. 4 but for La Niña years

The negative anomalies are directly associated with the warm dipole, because it relates to the ITCZ being north of its climatological position (Nobre and Shukla, 1996; Souza and Nobre, 1998). Thus, a sinking motion expected to the south of the ITCZ causes deficient precipitation over center-northern and western sectors of the Amazon. On the other hand, the presence of positive precipitation anomalies in the center-eastern Amazon cannot be directly related to the anomalous northern position of the ITCZ. A possible explanation is that other systems, like strong frontal systems in central and southern Brazil cause atmospheric instability, enhancing precipitation in the center-eastern Amazon.

The austral autumn composite shows negative values in almost the whole Amazon (Fig. 6b). It is interesting to recall that the ITCZ during the autumn reaches its most southern climatological position. Thus, the warm dipole impedes the southward seasonal

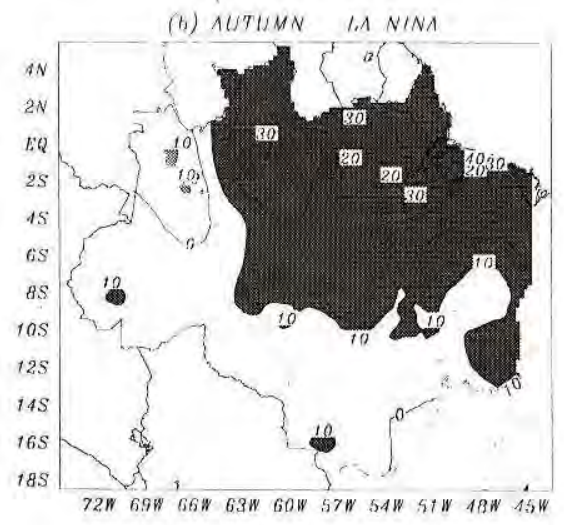

displacement of the ITCZ. This result reinforces the important role played by the ITCZ in modulating the autumn precipitation over the Amazon.

Figure 7 shows the austral summer and autumn anomalous precipitation composites ( $\mathrm{mm} / \mathrm{month}$ ) for cold dipole years. Except in small areas in the western and northeastern Amazon, the austral summer composites for cold (Fig. 7a) and warm (Fig. 6a) dipole years are not reversed. In fact, the austral summer composite for cold dipole years exhibits positive values in a relatively large portion of the southwestern Amazon. In contrast, the autumn composites for cold and warm dipole years are nearly reversed (compare Figs. $6 \mathrm{~b}$ and $7 \mathrm{~b}$ ). Figure $7 \mathrm{~b}$ shows positive precipitation anomalies extending over a large portion of the Amazon. The presence of cold dipole in the tropical Atlantic favors the anomalous southward displacement of the ITCZ during austral autumn, with consequent increase of rainfall over the Amazon. 

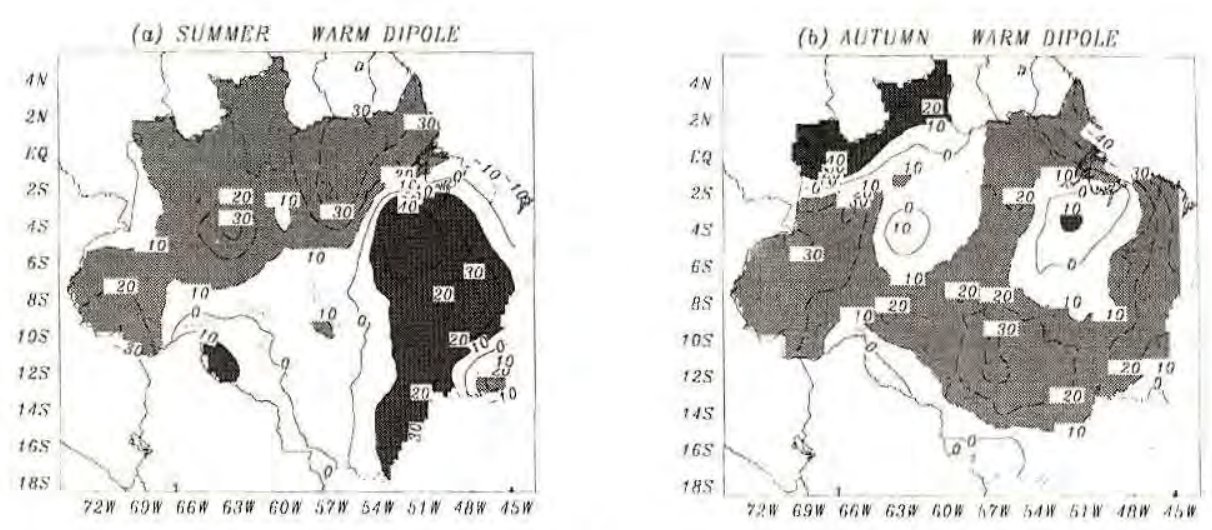

Figure 6. As in Figure 4 but for warm dipole years.
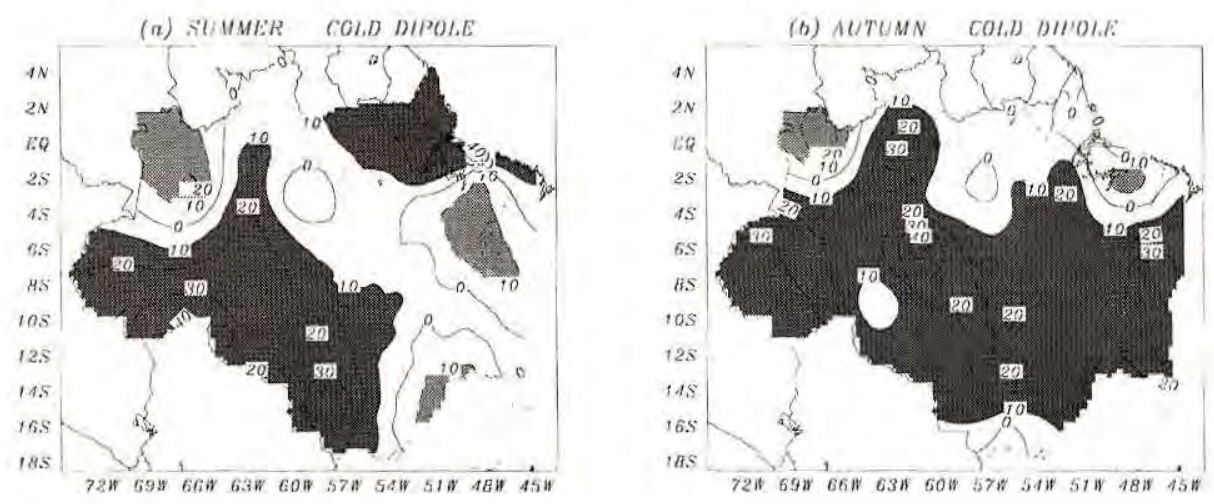

Figure 7. As in Figure 4 but for cold dipole years.

In order to have a better idea of the temporal evolution of the precipitation anomalies in each Amazonian state (Acre - AC, Amazonas - AM, Roraima - RR, Rondônia - RO, Amapá - AP, Pará - PA, parts of Maranhão - MA, Mato Grosso - MT and Tocantins - TO), monthly precipitation composites (for El Niño, La Niña, warm and cold dipole patterns) with the anomalies averaged for each state are obtained. The monthly composite values calculated for the austral summer and autumn months are dis-

played in Figure 8. Proximity of the curves indicates more similar behavior of the precipitation anomalies among the states. The outstanding aspect of these curves is the coherent effect (positive precipitation anomalies) for La Niña and cold dipole events in all Amazonian states during March and April. Although the anomalous values for these two months are not the largest, one can infer that under simultaneous occurrences of $\mathrm{La}$ Niña and cold dipole in the Atlantic, excessive precipitation over the Ama- 
zon would be expected during March and April. Similarly, El Niño and warm dipole in the Atlantic composites show negative precipitation anomalies for some Amazonian states during March and April. As not all Amazonian states show negative precipitation anomalies under the simultaneous occurrence of El Niño and warm dipole events, reduction of precipitation would be expected only in part of the Amazon region.

Another interesting aspect of these panels is the larger dispersion of the curves during summer months than during autumn months for all composites (El Niño, La Niña, warm and cold dipole patterns in the Atlantic). Considering the composites for one specific phenomenon (for instance, the $E l$ Niño) and for the austral summer months, opposite signs of the precipitation anomalies are seen for some states in relation to the others. This indicates a reversed effect of the same phenomenon on the precipitation for two distinct Amazonian areas.

Visual inspections of the graphs in Figure 8 to infer the combined effects of the El Niño and warm dipole on precipitation in the Amazon during austral summer and autumn might be biased in some areas. Thus, composites of the precipitation anomalies considering only the years with the occurrences of El Niño and warm dipole in the following year $(1965,1969,1979$ and 1991) are performed and displayed in Figure 9. It is worthwhile to recall that the selection of an $E l$
Niño year refers to austral summer SST data, while the selection of a warm dipole year refers to autumn SST data. Once an El Niño is established by the summer of a year it would continue throughout the autumn of the following year.

Comparisons of Figures 4a, 6a and 9a show that the El Niño and warm dipole have a stronger combined effect in reducing precipitation over the center-northern and western Amazon and in increasing precipitation in the eastern Amazon during austral summer than the two events acting individually. In fact, the lowest negative values over the center-northern Amazon are $-50 \mathrm{~mm} / \mathrm{month},-30 \mathrm{~mm} /$ month and $-100 \mathrm{~mm} / \mathrm{month}$ in Figures 4a and 6a and 9a, respectively. Positive anomalies of $50 \mathrm{~mm} / \mathrm{month}$ in the eastern Amazon due to the combined effects of El Niño and warm dipole in the Atlantic (Fig. 9a) are found in two nuclei which are of $40 \mathrm{~mm} / \mathrm{month}$ in the southeastern Amazon for the $\mathrm{El}$ Niño composite (Fig. 4a) and of the same magnitude in the northeastern Amazon for the warm dipole composite (Fig. 6a).

Otherwise, the autumn composites for the simultaneous occurrences of El Niño and warm dipole (Fig. 9b) and for the warm dipole only (Fig. 6b) show quite similar patterns with negative anomalies over the central, western and eastern Amazon. This result reveals a relatively weak effect of the El Niño on autumn rainfall in the Amazon region. 

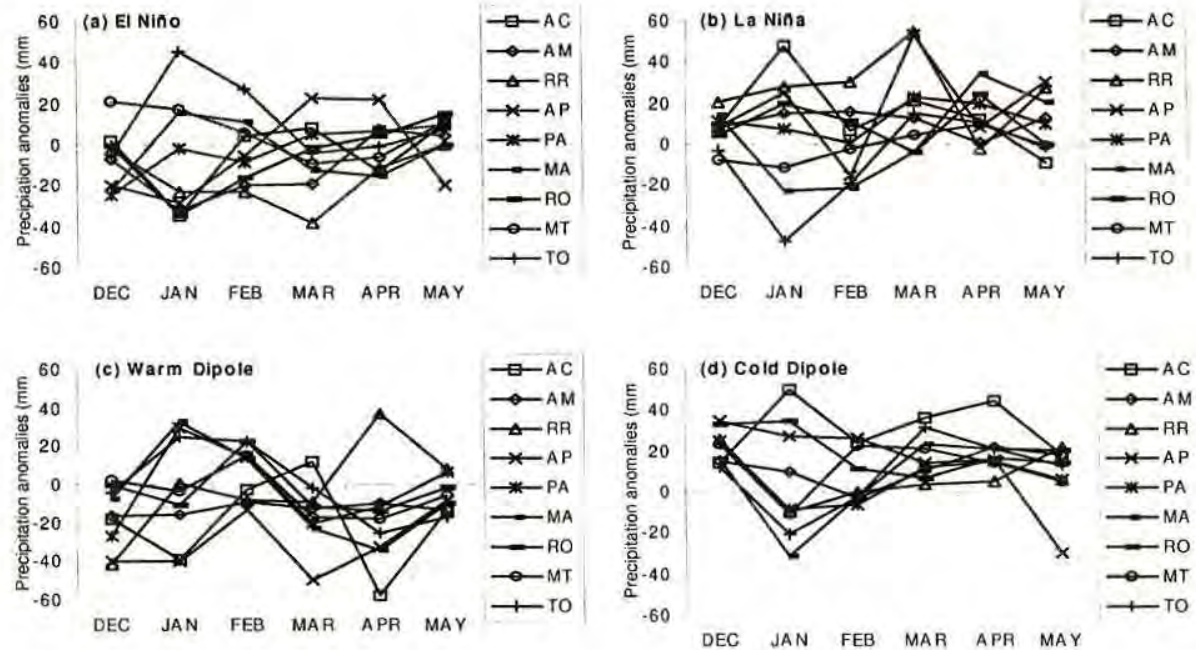

Figure 8. Monthly composite precipitation anomalies (mm) for (a) El Niño, (b) La Niña, (c) warm and (d) cold dipole for each Amazonian state (Acre - AC, Amazonas - AM, Roraima RR, Rondônia - RO, Amapá - AP, Pará - PA, and portions of Maranhão - MA, Mato Grosso MT and Tocantins - TO).

(a) SUMWER - EL NINO+ WARM DIPOLE

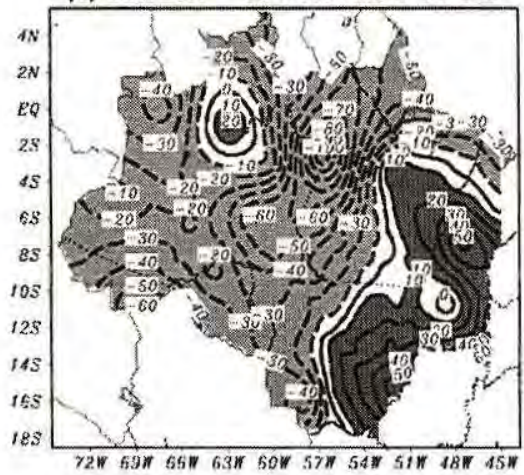

(b) AUTUMN - EL NINO+ WARM DIPOLE

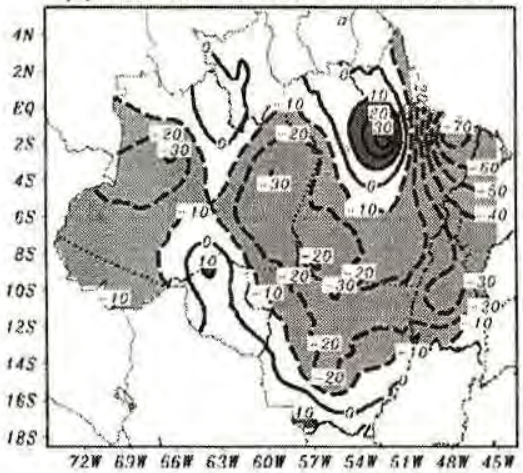

Figure 9. As in Fig. 4 but for years $(1965,1969,1979$ and 1991) of simultaneous occurences of EI Niño events and warm dipole.

\section{CONCLUSIONS AND SUGGESTIONS}

Thirty nine years of precipitation data over the Amazon and of tropical SST data are used to investigate the relationship between tropical SST variations and anomalous rainfall dis- tribution over the Amazon, in particular during the austral summer and autumn seasons. Precipitation composites for the Amazon are performed for austral summer and autumn seasons based on ENSO years and on the years with establishment of a north/south dipole pattern in the Atlantic. The 
composites for the ENSO years clearly show seasonal differences depending on the ENSO cycle phases. Summer composites for El Niño years and for $L a$ Niña years feature nearly reversed patterns, with the zero line approximately along a straight line defined by the points $\left(18^{\circ} \mathrm{S}, 57^{\circ} \mathrm{W}\right)$ and $\left(2^{\circ} \mathrm{S}, 51^{\circ} \mathrm{W}\right)$. El Niño (La Niña) composites show negative anomalies to the west (east) of the zero line and positive anomalies to the east (west) of this line. This suggests that the ENSO cycle modulates the summer rainfall over the Amazon in the east/west direction.

In contrast, the autumn composites for El Niño and La Niña years do not present reversed patterns. Indeed, it is noticeable that La Niña episodes have more pronounced influence on autumn rainfall over the Amazon compared to El Niño episodes. The Autumn composite for La Niña events shows positive anomalies over a large area in the center-eastern and northern Amazon. A possible explanation is that a favorable climatological condition for increased precipitation over the Amazon (ITCZ in its most southern position) during the austral autumn might be more easily maintained due the action of La Niña episodes than suppressed due the action of El Niño episodes.

Composites for north/south dipole years also exhibit seasonal differences depending on the phase of the dipole. Autumn composites for warm and cold dipole years show nearly reversed patterns with negative (positive) anomalies over almost the whole
Amazon for warm (cold) dipole. It therefore seems that the north/south dipole acts to modulate the ITCZ intensity and positioning. On the other hand, the summer composites do not show a clear relation to the ITCZ intensity and position.

The combined effect of $E l$ Niño and warm dipole in the Atlantic has been analyzed. For summer, these two climatic modes have a stronger combined effect in reducing precipitation over the center-northern and western Amazon and in increasing precipitation over the eastern Amazon than each mode acting individually. $\mathrm{Re}$ duced autumn precipitation over the Amazon is, however, almost entirely due to the warm dipole rather than due to the El Niño episode.

The results above suggest that the effects of El Niño, La Niña, warm dipole and cold dipoles in the Atlantic as reflected in the anomalous rainfall distribution over the Amazon contain a seasonal component defined by the regional atmospheric circulation, which in turn relates to the seasonal variations of the Hadley and Walker Cells. This aspect seems to be a relevant factor in climate monitoring tasks.

\section{ACKNOWLEDGMENTS}

The authors thank the two anonymous reviewers for their helpful comments. The first authors was supported by FAPESP under grant number 98/02479-0; the second author was partially supported by CNPq under grant number 300033/94-0. 


\section{Literature cited}

Cohen, J. C. P.; Silva Dias, M. A. F.; Nobre, C. A. 1995. Environmental conditions associated with Amazonian Squall Lines: a case study, Monthly Weather Review, 123(11): 3163-3174.

Da Silva, A. M.; Young, C. C.; Levitus, S. 1994. Atlas of surface marine data 1994. Vol.1: Algorithms and procedures. NOAA ATLAS NESDIS 6, Washington. 83 pp.

Figueroa, S. N.; Nobre, C. A. 1990. Precipitation distribution over central and western tropical South America. Climanálise, 5(6): $36-45$.

Figueroa, S. N.; Satyamurty, P.; Silva Dias, P. L. 1995. Simulations of the summer circulation over the South America region with an eta coordinate model. Journal of the Atmospheric Sciences, 52: 1573-1584.

Fisch, G.; Marengo, J. A.; Nobre, C. A. 1998. Uma revisão geral sobre o clima da Amazônia. Acta Amazonica, 28(2): 101126.

Jones, C.; Horel, J. D. 1990. A note on the upper level divergence field over South America during the summer season. Revista Brasileira de Meteorologia, 5(2): 411-416.

Kayano, M. T.; Moura. A. D. 1986. O El Niño de $1982-83$ e a precipitação sobre a América do Sul. Revista Brasileira de Geofisica, 4(1-2): 201-214.

Kousky, V. E. 1985. Atmospheric circulation changes associated with rainfall anomalies over tropical Brazil. Monthly Weather Review, 113: 1951-1957.

Kousky, V. E.; Kayano, M. T. 1981. A climatology study of the tropospheric circulation over the Amazon region. Acta Amazonica, 11(4): 743-758.

Kousky, V. E.; Kayano, M. T.; Cavalcanti, I. F. A. 1984. A review of the Southern Oscillation: oceanic-atmospheric circulation changes and related rainfall anomalies. Tellus, 36A(5): 490-504, 1984.

Kousky, V. E.; Ropelewski, C. F. 1989. Extremes in the Southern Oscillation and their relationship to precipitation anoma- lies with emphasis on the South American region. Revista Brasileira de Meteorologia, 4: 351-363.

Marengo, J.; Hastenrath, S. 1993. Case studies of extreme climatic events in the Amazon basin. Journal of Climate, 6(4): 617627.

Marengo, J.; Nobre, C. A.; Culf, D. A. 1997. Climatic impacts of the "Friagens" in forested and deforested areas of the Amazon Basin. Journal of Climate, 36(11): 15531556.

Molion, L. C. B. 1987. Climatologia dinâmica da região Amazônica: mecanismos de precipitação. Revista Brasileira de Meteorologia, 2(1): 107-117.

Moura, A. D.; Shukla, J, 1981. On the dynamics of droughts in northeast Brazil: observations, theory and numerical experiments with a general circulation model. Journal of the Atmospheric Sciences, 38(7): 26532675.

Nobre, C. A. and Rennó, N. O. 1985. Droughts and floods in South America due to the 1982-83 El Niño/Southern Oscillation episode. 16th Conference on Hurricanes and Tropical Meteorology, American Meteorological Society, Houston, TX, 1985. p.131-133.

Nobre, P.; Shukla, J. 1996 Variations of sea surface temperature, wind stress and rainfall over the tropical Atlantic and South America. Journal of Climate, 9(4): 2464 2479 .

Obregon, G. O.; Nobre, C. A. 1990, Principal component analysis of precipitation fields over the Amazon river basin. Climanálise, 5(7): 35-46.

Oliveira, A. D.; Nobre, C. A. 1985. Meridional penetration of frontal system in South America and its relation to organized convection in the Amazon. 16th. Conference on Hurricanes and Tropical Meteorology, American Meteorological Society, Houston, TX, 1985. p.85-87.

Paegle, J.. 1987. Interactions between convection and large scale motions over Amazonia. In: Dickinson, R.E. (Ed.). The geophysiology of Amazonia: vegetation 
and climate interactions. Wiley Series, New York. 526pp.

Quadro, M. F. L.; Batista, N.N.M.; Calbete, N.O. 1996. Climatologia de precipitação e temperatura no Brasil. Climanálise Especial, vol. único: 90-100.

Rao, V. B.; Hada, K. 1990. Characteristics of rainfall over Brazil: annual variations and connections with the Southern Oscillation. Theoretical and Applied Climatology, 42: 81-91.

Reynolds, R. W. 1988. A real time global sea surface temperature analysis. Journal of Climate, 2: 268-284.

Ropelewski, C. F.; Halpert, M. S. 1987. Global and regional scale precipitation patterns associated with the $\mathrm{El}$ Niño/Southern Oscillation. Monthly Weather Review, 115(2): 1606-1626.

Souza, E. B.; Nobre, P. 1998. Uma revisão sobre o Padrão de Dipolo no Oceano Atlântico tropical. Revista Brasileira de Meteorologia, 13(1): 31-44.

Trenberth, K. E. 1998. The definition of El Niño. Bulletin of the American Meteorological Society, 78(12): 2771-2777.

Wagner, R.G. 1996. Mechanisms controlling variability of the interhemispheric sea surface temperature gradient in the tropical Atlantic. Journal of Climate, 9(7): 20102019. 